\author{
Soroka T. V., \\ Ph. D. in Philology, \\ Associate Professor at the Department of the English Philology \\ Izmail State University of Humanities
}

\title{
DICTIONARY ENTRY AS A MEANS OF EXPLICIT EXPRESSIVENESS OF AN AXIONOMEN SEMANTIC STRUCTURE
}

\begin{abstract}
Summary. The purpose of the article is to justify the role of explanatory dictionaries CYM, OED and DLF that form the empirical basis for investigating the lexical semantics of nouns denoting values. The analysis of lexicographic resources has contributed to the collection of language research material, and the definitive analysis has helped in the study of lexical meanings of nouns denoting values, which is reflected in their dictionary interpretations. In explanatory dictionaries, system connections of lexical units are objectified, since the definition of the meanings of some words is carried out by using other words of the same language that are semantically related to the former ones. In the process of lexicographic processing language semantics of nouns for the designation of values in Ukrainian, English and French, the main thing is to determine the volume of lexical meanings of register words, which is accompanied by the study of their system dependencies and the establishment of a place among other homogeneous register units. The conventionality of the relationship between the form and content of language signs denoting values overlaps with the systemic and structural motivation of the expression plan and the content plan. The development of a dictionary article in lexicographic resources of an explanatory nature occurs on the basis of three main characteristics: dictionary definitions (the actual paradigmatic part of the dictionary entry), illustrative material (its syntagmatic part), and a system of marks. The structure of dictionary entries of axionomens is determined by the volume and qualitative specifics of the individual lexical meaning synthesized on the basis of complexes of micro-structural relations. Depending on this, dictionary entries of various complexity divide the lexical meanings of polysemantic axiomens into rubrics and sub-rubrics (shades of meanings), which in turn are formed from formulas of interpretation. In three dictionaries, the division into rubrics is equally numbered, and the selection of sub-rubrics is carried out by their individual designation.
\end{abstract}

Key words: registry word, explanatory dictionary, axionomen, definition analysis, interpretation formulae, lexical semantics.

Problem statement. Recently, in Ukrainian linguistics, there has been an activation of formalized researches of system and structural features of lexical semantics in order to conduct its multidimensional parameterization, based on the principles of matrix representation of semantic relations between language units denoting the realities of the world picture. Following the general tendency, the vocabulary of the modern Ukrainian, English and French languages is considered as a system, an integral organization with interconnected and interdependent areas, which, in turn, have specific properties, but are subject to the laws of the existence of this integrity.

The terms system and structure in the modern Russian and Ukrainian linguistic literature are different. Definitions of the system and structure are distinguished in Russian linguistic works as follows: if the system is a set of elements connected by certain relations, then the structure is a type of these relations, a way of organizing the system. If we know the structure of the system (subsystems, their internal structure and the type of connection between their elements), we can say that we know the structure of the system itself [10, p. 452-454]. In Ukrainian linguistics, the concepts of system and structure are interpreted as inseparable components of the object of language: the structure and system of language - two aspects of an objectively unified relationship between language, which is considered as an organized set of components and elements, and these components and elements [11, p. 319]. We adhere to the definitions of the considered terms in the interpretation of $\mathrm{O}$. S. Melnichuk: a system in a language is understood as a set of interrelated, mutually-conditioned elements that form a more complex unity, considered by the elements - its parts, and a structure - the composition and internal organization of a single whole, considered in terms of its integrity [11, p. 607].

The system and structure of the Ukrainian, English and French literary languages are more naturally and voluminously represented by explanatory dictionaries, which are the most complete banks of information about language units [6, p. 19] and act as snapshots of constantly updated and moving language $[1$, p. 8]. In the dictionaries used in the study $[12 ; 13 ; 14]$, as in the process of using language, phonology, morphology and word formation are not allocated to autonomous systems or subsystems, but act as a complex form of expressing the content of lexical units.

Lexicographic practice of compiling explanatory dictionaries aimed researchers at studying the lexical meaning of a word not as an isolated, but as an organically combined element of the language system. Accordingly, such authoritative explanatory dictionaries as CYM, OED and DLF allow us to analyze the linguistic means of their expressions in terms of semantic components [3]. Determining the lexical meanings of words as facts of language is carried out by lexicographers by studying texts as the results of human speech activity. Determination of lexical meanings of words as facts of language is carried out by lexicographers by studying texts as results of human speech activity. Thus, nouns for denoting values in an explanatory Dictionary combine the form of expression and content. The form of a word is a multi-faceted phenomenon, thanks to which the lexical meaning manifests itself in its entirety.

Analysis of recent researches and publications. The general scientific basis of the work is the principle of anthropocentrism, which is understood in the projection on ethnocentrism, expansionism and explanatorism. The study uses general scientific methods (analysis, synthesis, induction and deduction), which are supplemented with special linguistic methods. Thus, the analysis of lex- 
icographic resources has contributed to the collection of language research material, and the definitive analysis has helped in the study of lexical meanings of nouns denoting values, which is reflected in their dictionary interpretations.

In a number of articles devoted to the characteristics of lexical-semantic groupings of axionomens ${ }^{1}[4 ; 5]$, the results of scientific research of words with the highest, average degree of polysemy and monosemic lexemes, which qualify as value-determined register units of lexicographic resources of an explanatory nature, have been presented. In this regard, the need to resolve the issue of disclosing the principles of definitive analysis and the nature of the relations of axionomens of various degrees of polysemy determines the relevance of the stated problem.

The purpose of the article is to substantiate the role of explanatory dictionaries that form an empirical basis for studying the lexical semantics of nouns designating values. Achieving the goal involves solving the following tasks: 1) to reveal the essence of the dictionary article from the point of view of its main characteristics; 2) to establish the practical significance of definitive analysis as a formalized basis for the study of Ukrainian, English and French axionomens.

Presentation of main material. In explanatory dictionaries, system connections of lexical units are objectified, since the definition of the meanings of some words is carried out by using other words of the same language that are semantically related to the former ones.

In the process of lexicographic processing language semantics of nouns for the designation of values in three languages, the main thing is to determine the volume of lexical meanings of register words, which is accompanied by the study of their system dependencies and the establishment of a place among other homogeneous register units. System dependencies, indicating the place and delineating the boundaries of the individual meaning assigned to the register word, notes M.M. Peshchak, are interpreted by a rich but almost foreseeable arsenal of structural schemes for organizing dictionary entries [2, p. 11]. In the scientific work, we proceed from the fact that the studied vocabulary, acting in the dictionary as value-conditioned register words of Ukrainian, English and French, is distinguished on the basis of lexicographic parameters that are fully determined by the type of dictionary - CYM, OED and DLF.

The explanatory dictionaries are used as a source base for factual material. The definitions of the researched words in CVM, OED i DLF serve as the basis for describing their meanings, where each individual interpretation represents one of the axionomen meaning. So, the analyzed lexical unit, which corresponds to N-interpretations in the dictionary, is characterized as N-significants. The left part of the dictionary article contains what is known before definding, while the right part in a dissected form contains what becomes known after definding. In this case, the left part represents the form (the expression plan) of the word, and the right part represents its lexical meaning (the content plan). Both the expression plan and the content plan appear as multicomponent and complex system-structural units, but this complexity is so simply described that the user of the dictionary hasn't misunderstandings that would relate to the unity of the lexicographic word as a language sign

Axionomen (from the Greek $\alpha$ si $\alpha$ - "value" and Latin nomen - "name, denomination, appellation, designation") is a working term introduced into scientific use by the author (Soroka T.V.) to denote philosophical, world outlook, scientific, social, political, moral, religious, legal, aesthetic values.
[2, p. 15]. The conventionality of the relationship between the form and content of language signs denoting values overlaps with the systemic and structural motivation of the expression plan and the content plan. A dictionary article is a complex of formal features with a specific structure, from which no part can be removed or to which no part can be added, so as not to change other parts and cause a general regrouping [7, p. 204]. In addition, the lexical meaning of a word itself is determined not only as its direct (or indirect) correlation with a specific (or abstract) object. The meaning of the word reflects both general subject-logical connections, and relations with the lexical meanings of other words of this (or approximate) lexical paradigm, and the limits of lexical compatibility, and the nature of lexical-grammatical attribution (that is why dictionaries indicate the part of speech to which a certain word belongs, as well as general formal-categorical meanings) and the emotional-expressive properties inherent in the word $[9, \mathrm{p} .126]$.

The development of a dictionary entry in lexicographic resources of an explanatory nature occurs on the basis of three main characteristics: dictionary definitions (the actual paradigmatic part of the dictionary article), illustrative material (its syntagmatic part), and a system of marks. When studying lexical units for the designation of values, we take into account these indicators.

The structure of dictionary entries of axionomens is determined by the volume and qualitative specifics of the individual lexical meaning synthesized on the basis of complexes of micro-structural relations. Depending on this, dictionary entries of various complexity divide the lexical meanings of polysemantic axiomens into rubrics and sub-rubrics (shades of meanings), which in turn are formed from formulas of interpretation. In three dictionaries, the division into rubrics is equally numbered, and the selection of sub-rubrics is carried out by their individual designation.

1) In СУМ - by slashes: життя, -я, c. 1. Вища форма існування матерії, найхарактернішими рисами якої є обмін речовин, самооновлення, самовідтворення. // Існування всього живого; прот. смерть. 2. Стан живого організму в стадії розвитку, зросту. 3. Період існування кого-небудь; вік. // Все пережите, зроблене людиною за час іiі існування; біографія. 4. Спосіб існування кого-небудь. 5. Жива істота. 6. перен. Про щось дороге, необхідне, важливе. 7. Прояв фізичних і духовних сил живих істот. 8. Пожвавлення, рух, посилення діяльності живих істот. 9. Сукупність явищ, що характеризують існування, визначають розвиток чого-небудь. 10. Те, що реально існує; дійсність.

2) In OED - by squares: life $-n$ (pl. lives) 1 . [mass noun] The condition that distinguishes animals and plants from inorganic matter, including the capacity for growth, reproduction, functional activity, and continual change preceding death. - living things and their activity. 2. The existence of an individual human being or animal. - [with adjective or noun modifier] A particular type or aspect of human existence. - A biography. - (in Christianity and some other religious traditions) either of the two states of a person's existence separated by death. - (in Hinduism and some other religious traditions) any of a number of successive existences in which a soul is held to be reincarnated. - A chance to live after narrowly escaping death (with reference to the nine lives traditionally attributed to cats). - (in various games) one of a specified number of chances each player has before being put out. 3. (usually one's life) The period between the birth and death of a living thing, especially a human being. - The period during which something inani- 
mate or abstract continues to exist, function, or be valid. - informal [mass noun] A sentence of imprisonment for life. 4. Vitality, vigour, or energy. 5. [mass noun] (in art) the depiction of a subject from a real model, rather than from an artist's imagination.

3) In DFL - by capital letters: vie - n.f. (latin vita) A.I.1. Ensemble des phénomènes (nutrition, assimilation, croissance, reproduction) communs aux êtres organisés et qui constituent leur mode d'activité propre, de la naissance à la mort. 2. Fait de vivre, existence humaine. - Relig. Bonheur éternel des élus après la mort. 3. Entrain, vitalité manifestés das tous les comportements. A.II.1. Existence humaine considérée dans sa durée; ensemble des évènements qui se succèdent dans cette existence. 2. Manière de vivre propre à qqn ou à un groupe. 3. Ensemble des activités de qqn dans un domaine spécifique. 4. Ensemble des moyens matériels (aliments, argent, etc.) nécessaires pour assurer l'existence de qqn. 5. Condition humaine, monde des humains. 6. Biographie, histoire de qqn. B.1. Mouvement, dynamisme, élan, vitalité qui caractérisent quelqu'un, une action, une œuvre, animent un lieu. 2. Ensemble des activités, des situations, des relations entre personnes qui marquent l'existence et le fonctionnement d'un secteur, d'un groupe. 3. Existence, dans le temps, des choses soumises à une évolution.

The analysis of the lexicographic representation of the studied language units has shown that one dictionary entry intersecting with others forms certain groupings with them, which at the lexical level form synonymous rows. There is also an intersection of one dictionary entry with another one, and further that one with another one, but different from the first one by formal features [8, p. 20-21].

Formulas of interpretation, their relationship within the same rubric and between rubrics form the essence of the structure of the explanatory part, and the features of the design of the register unit and its relationship with the explanatory part form the structure of the dictionary article.

In dictionary entries of monosemantic Ukrainian, English, and French register axiomens, there is no rubrication, and the difference in the volume of their lexical meanings is conveyed by detailing the interpretation. Compare: $\underline{\mathbf{U k r}} .:$ ввічливість (увічливість), -вості, ж. Властивість за знач. ввічливий, консенсус, -у, ч. Відсутність у сторін, що домовляються, заперечень проти пропозицій, висунутих під час переговорів; Eng.: politeness (noun) The act of showing regard for others, consensus (noun) General agreement among a group of people; $\underline{F r}$.: civilité n.f. (latin civilitas, -atis) Observation des convenances en usage chez les gens qui vivent en société, consensus n.m. (latin consensus, accord) Accord et consentement du plus grand nombre, de l'opinion publique.

These examples show that in unambiguous axionomens, formal features refer to the undifferentiated lexical meaning of a register unit, so no matter how many of them there are in a dictionary entry, each appears only once.

The dictionary entry is a group in which formal features are strictly organized. The number of formal features depends on the degree of polysemy of the register word: the richer the polysemy, the more grounds for a variety of formal features of the dictionary article. Thus, the stylistic properties of the lexical meaning of a register unit and its shades are presented in the form of remarks, for example: $\underline{\mathbf{U k r}} .:$ добро: 2. у знач. присудк. сл. (=у значенні присудкового слова) Про задоволення, що його хто-небудь відчуває від певного становища, певних обставин і т. ін., 4. ірон. (=іронічне слово). Про щось погане, недоброякісне, незначне і т. ін., мир: II.4. заст. (=застаріле слово) Життя мирян; світське життя, на протилежність монастирському, мораль: 3. розм. (=розмовне слово) Повчання, настанови, поради; Eng.: law: 1. - (the law) informal (=in informal speech) The police, art: 15.

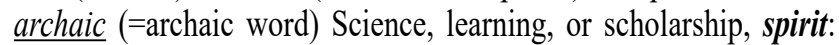
1. - short for (short word for smth.) Holy Spirit; Fr.: amour: III. pl. (=pluriel) Suisse. Dernières gouttes d'une bouteille de vin, vie: A.II.4. - Fam. (=familier) Faire la vie. a. S'adonner, souvent avec excès, à tous les plaisirs. b. Etre insupportable, liberté: V.2. - Fig. (=figuré) Prendre des libertés avec un texte, ne pas le citer (ou le traduire, etc.) exactement.

Other physically-expressed signs of axionomen are terminologized and indicate the scope of its use. So, directly before the formula of interpretation in dictionary entries, one can get along with the abbreviations or full names of doctrines, theories, branches of knowledge or occupations, such as: $\underline{\mathbf{U k r}}$ : $\underline{\mathrm{icm}}$. (=історія) воля: звільнення селян від кріпацтва, мат. (=математика) порядок: числова характеристика багатьох математичних об'єктів; Eng: Mathematics. space: a mathematical concept regarded as a geometric set of points governed by axioms, Botany. style: flower part, Christianity. soul: the spiritual part of a person, capable of redemption from the power of sin through divine grace; $\mathbf{F r}$.: Géométrie. espace: ensemble des points dont la position est définie par trois coordonnées, Sports. 2. droit n.m. (lat. directum, ce qui est droit): 1. Pied ou poing droit, 2. Coup porté avec le poing droit, en boxe.

Conclusions. The presented issues concerning the role of explanatory dictionaries that form the empirical basis for investigating the lexical semantics of nouns denoting values stress that the dictionary entry contains a set of formal features that help to identify and characterize both well-known, national features of words, and their national-language specifics, and discard random features that appear in certain contexts. Since a dictionary entry acts as a tool for interpreting the lexical meaning of a register unit, its intersection with other but distinctive formal features makes it possible to formalize the relationship between lexical meanings in the language system.

The prospect of research is to analyze language objectivization of Ukrainian, English and French cultural axiological categories presented with words denoting philosophical, world outlook, scientific, social, political, moral, religious, legal, aesthetic values in comparative typological analysis.

\section{References:}

1. Апресян Ю.Д. Прагматическая информация для толкового словаря. Интегральное описание языка и системная лексикография : избранные труды. Москва : Языки русской культуры, 1995. T. 2. C. $135-154$.

2. Пещак М.М. Специфіка формальних ознак лексикографічної обробки слова. Формалізовані основи семантичної класифікаиії лексики. Київ : Наукова думка, 1982. С. 10-55.

3. Скороходько Э.Ф. Семантические сети и автоматическая обработка текста. Киев : Научная мысль, 1983. 218 с.

4. Сорока Т.В. Матричне представлення аксіономенів із середнім ступенем полісемії (на матеріалі сучасної української мови). Мова i культура. 2013. Вип. 16. Т. III (165). С. 167-175.

5. Сорока Т.В. Особливості системного співвідношення українських та англійських аксіономенів. Сучасні дослідження з іноземної філологіï. 2016. Вип. 14. С. 197-207.

6. Фабіан М.П. Етикетна лексика в українській, англійській та угорській мовах : монографія. Ужгород : Інформаційно-видавниче агентство «IBA», 1998. 255 с. 
7. Фабіан М.П. Застосування процедури формалізованого аналізу лексичної семантики в зіставних дослідженнях. Проблеми зіставної семантики. 2011. Вип. 10. Ч. І. С. 202-207.

8. Клименко Н.Ф., Пещак М.М., Савченко І.Ф. Формалізовані основи семантичної класифікації лексики. Київ : Наукова думка, $1982.250 \mathrm{c}$

9. Шхапацева М.Х. К вопросу о лексическом значении слова. Вестник Адыгейского государственного университета. Серия: Филология и искусствоведение. 2014. Вып. 1. С. 121-127.

10. Ярцева В.Н. Лингвистический энциклопедический словарь. Москва : Советская энциклопедия, 1990. 685 с.

11. Українська мова: енциклопедія / за ред. В.М. Русанівського, О.О. Тараненка. Київ : Українська енциклопедія, 2000. 752 с.

12. СУМ - Словник української мови : у 11 т. / ред. І.К. Білодід та ін. Київ : Наукова думка. Т. 1. 1970. 799 с.; Т. 2. 1971.550 с.; Т. 3. 1972. 744 c.; T. 4.1973 .840 c.; Т. 5. 1974.840 c.; T. 6. 1975.832 c.; Т. 7. 1976. 723 c.; T. 8.1977 .927 c.; T. 9.1978 .916 c.; T. 10. 1979.658 c.; T. 11. 1980. 699 c.

13. DLF - Grand Larousse de la Langue Française : en 7 vol. / sous la direction de L. Gilbert, R. Lagane, G. Niobey, avec le concours de H. Bonnard, L. Casati, A. Lerond. Paris : Larousse, 1986. 6528 p.

14. OED - Oxford English Dictionary : in 12 vol. / chief ed. J. Murray. London : Oxford University Press, 1963. V. I. 1240 p.; V. II. 1308 p.; V. III. 488 p.; V. IV. 532 p.; V. V. 758 p.; V. VI. 820 p.; V. VII. 1216 p.; V. VIII. 936 p.; V. IX. 386 p.; V. X. 396 p.; V. XI. 493 p.; V. XII. 105 p.

Сорока Т. В. Словникова стаття як засіб експліцитного вираження семантичної структури аксіономена

Анотація. Мета дослідження полягає в обгрунтуванні ролі тлумачних словників (СУM, OED i DLF), що утворюють емпіричну базу для вивчення лексичної семантики іменників на позначення цінностей. Аналіз лексикографічних джерел сприяв збору мовного матеріалу дослідження, а дефініційний аналіз допоміг у вивченні лексичних значень іменників на позначення цінностей, що відображено в їхніх словникових тлумаченнях. В тлумачних словниках об'єктивуються системні зв'язки лексичних одиниць, оскільки визначення значень одних слів здійснюється за допомогою інших слів тієї самої мови, семантично пов'язаних 3 першими. В процесі лексикографічної обробки мовної семантики іменників на позначення цінностей в українській, англійській та французькій мовах основним $€$ визначення обсягу лексичних значень реєстрових слів, яке супроводжується дослідженням їх системних залежностей та встановленням місця серед інших однорідних реєстрових одиниць. Конвенціональність зв'язку між формою і змістом мовних знаків на позначення цінностей перекривається системною та структурною вмотивованістю плану вираження й плану змісту. Розгортання словникової статті в лексикографічних джерелах тлумачного характеру відбувається на основі трьох основних характеристик, a саме словникових дефініцій (власне парадигматичної частини словникової статті), ілюстративного матеріалу (iï синтагматичної частини) та системи позначок. Будова словникових статей аксіономенів обумовлена обсягом і якісною специфікою синтезованого на основі комплексів мікроструктурних відношень індивідуального лексичного значення. Залежно від цього словникові статті найрізноманітнішої складності розбивають лексичні значення полісемантичних аксіономенів на рубрики й підрубрики (відтінки значень), які утворюються з формул тлумачення. В трьох словниках розбивка на рубрики однаково нумерується, а виділення підрубрик здійснюється шляхом їх індивідуального позначення. Аналіз лексикографічного представлення досліджуваних мовних одиниць показав, що одна словникова стаття під час перетину 3 іншими утворює з ними певні угруповання, які на лексичному рівні формують синонімічні ряди.

Ключові слова: реєстрове слово, тлумачний словник, аксіономен, дефініційний аналіз, формула тлумачення, лексична семантика. 